\title{
Determination of Acrylamide in Aquatic Environmental Samples by $\mathrm{GC} / \mathrm{MS}$
}

\author{
Dae-Young $\mathrm{Yu}^{1,+} \cdot \mathrm{Ha}-\mathrm{Neul} \mathrm{Seo}^{2} \cdot$ Cheol-Hyeon Chang ${ }^{3}$ \\ ${ }^{1}$ Department of Environmental Engineering, Hanbat National University \\ ${ }^{2} B \& G$., R\&D Center \\ ${ }^{3}$ Department of Civil and Environmental Engineering, Hanbat National University
}

(Received September 6, 2019; Revised October 17, 2019; Accepted October 18, 2019)

Objectives: This study was conducted to improve the analysis method used for acrylamide (AA) and to investigate the occurrence of AA in influent and effluent from sewage treatment plants in Korea. A liquid chromatography coupled to tandem mass spectrometry (LC-MS/MS) is commonly used for AA analysis of complex samples because it is fast, simple and effective. However, the disadvantages of LC-MS/MS include its relatively high operational cost, low sample throughput, and low sensitivity. Therefore, this study was conducted to develop a novel analytical method for the determination of AA in complex environmental waters using gas chromatography-mass spectrometry (GC/MS) combined with the derivatization with bromine following solid-phase extraction (SPE).

Methods: This work describes the development of a novel SPE and GC/MS method for the analysis of AA in complex environmental waters. SPE parameters such as absorbent type, desorption solvent and volume were optimized by conducting a series of experiments. The best SPE cartridge was selected by conducting the recovery test with four different absorbents cartridge (Supelclean ${ }^{\mathrm{TM}}$ Coconut Charcoal cartridge, Supelclean ${ }^{\mathrm{TM}}{ }_{\mathrm{ENVI}}{ }^{\mathrm{TM}}-$ Carb Tubes, Cleanert ODS C18 and Oasis HLB Cartridges). The brominated derivative, 2,3-dibromopropionamide (2,3-DBPA), was extracted with ethyl acetate (EA) and analyzed by GC/MS in selected ion monitoring (SIM), employing $\mathrm{d}_{3}$-acrylamide $\left(\mathrm{d}_{3}\right.$-AA) as internal standard prior to extraction. Method validation was performed in terms of linearity of standard calibration curve, method detection limit (MDL), limit of quantification (LOQ), accuracy and precision of reaction product 2,3-DBPA.

Results and Discussion: Based on the SPE experimental results, the active carbon SPE was selected as it gave the best adsorption efficiency $(98.8 \%)$. The effects of $\mathrm{pH}$ and optimum bromine reaction time were found to be important determining factors for acrylamide analysis in water. The experimental results showed that the optimal reaction conditions of $\mathrm{pH}$ were 1.5 and $3 \mathrm{~h}$, respectively. The validation process consisted of assessing the following parameters: linearity of standard calibration curve, method detection limit (MDL), limit of quantification (LOQ), precision and accuracy. The coefficients of determination $\left(\mathrm{R}^{2}\right)$ in laboratory conditions were: $\mathrm{R}^{2}=0.9981(2.5 \sim 100 \mu \mathrm{g} / \mathrm{L})$. MDL and LOQ of acrylamide were $1.19 \mu \mathrm{g} / \mathrm{L}$ and $3.79 \mu \mathrm{g} / \mathrm{L}$, respectively. The recovery studies were carried out at two different concentration levels $(10 \mu \mathrm{g} / \mathrm{L}$ and $50 \mu \mathrm{g} / \mathrm{L}, \mathrm{n}=3)$. The intraday accuracy and precision were in the range of 100.6 102.0\% and 3.2 3.5\%, respectively, and the interday accuracy and precision were in the range of $96.0 \sim 97.4 \%$ and $4.3 \sim 8.0 \%$, respectively. The AA contents in effluents of sewage treatment plants were in the range of $0.008 \sim 0.017 \mu \mathrm{g} / \mathrm{L}$ for May, 0.009 0.14 $\mu \mathrm{g} / \mathrm{L}$ for June and not detected (N.D.) $0.02 \mu \mathrm{g} / \mathrm{L}$ for July samples.

Conclusions: An efficient analytical method for the determination of AA has been developed. Activated carbon SPE cartridge (Supelclean ${ }^{\mathrm{TM}}$ Coconut Charcoal) was selected for the sample purification. The validation study showed that this method was a reliable method with high sensitivity, linearity, precision, and accuracy. The interday accuracy and precision were in the range of $96.0 \sim 97.4 \%$ and $4.3 \sim 8.0 \%$, respectively. This method was successfully applied to the determination of AA in effluent waters of sewage treatment plants. The AA contents in effluents of sewage treatment plants were in the range of $0.008 \sim 0.017 \mu \mathrm{g} / \mathrm{L}$ for May, $0.009 \sim 0.14 \mu \mathrm{g} / \mathrm{L}$ for June and not detected (N.D.) $0.02 \mu \mathrm{g} / \mathrm{L}$ for July samples.

Key words : Acrylamide, Bromination, GC/MS, SPE 


\title{
연구논문
}

\section{고체상추출법과 $\mathrm{GC} / \mathrm{MS}$ 를 이용한 수질 환경 시료 중 아크릴아마이드 분석방법 연구}

\author{
유대영 ${ }^{1+} \cdot$ 서하늘 $^{2} \cdot$ 장철현 $^{3}$ \\ ${ }^{1}$ 한밭대학교 환경공학과 \\ ${ }^{2}$ (주)비앤지 기업부설연구소 \\ 3 한밭대학교 건설환경공학과
}

목적 : 본 연구는 수질 측정용 시료에서 아크릴아마이드에 관한 분석방법이다. 추출과 정제를 동시에 할 수 있는 $\mathrm{SPE}$ 법을 적용하고 가스크로마그래피/질량분석법을 이용하였다. 시판되고 있는 4가지 SPE 상품(Supelclean ${ }^{\mathrm{TM}}$ Coconut Charcoal, ENVI ${ }^{\mathrm{TM}}$ - Carb, ODS C18, Oasis HLB)을 비교 분석하였다. 또한, 유도체화 반응의 최적화를 통 하여 특정수질유해물질로 알려진 아크릴아마이드 분석의 최적조건을 확립하기 위하여 수행되었다.

방법: 하수종말처리장의 아크릴아마이드를 분석하기 위한 최적의 SPE 카트리지 선정은 특성이 다른 Coconut Charcoal, ENVI ${ }^{\mathrm{TM}}$-Carb, ODS C18 및 Oasis HLB의 4종류에 대하여 아크릴아마이드 표준용액을 카트리지에 흘려 준 다음 건조하고 탈착하여 회수율로 최적의 카트리지를 선정하였다. 탈착용매의 부피는 카트리지에 흡착된 아크 릴아마이드가 완전히 탈착하는 메탄올의 부피로 결정하였다. 브롬 유도체화 반응의 최적 시간, 최적 $\mathrm{pH}$ 및 반응 생성물의 추출 용매를 선정하기 위한 실험을 수행하였다. 최적 반응시간은 표준용액에 브롬 유도체화 시약을 첨 가하여 일정 시간마다 시료를 채취하여 분석한 회수율로 결정하였다. 추출용매의 선정은 유도체화 반응생성물을 $\mathrm{EA}$, dichloromethane (DCM), diethyl ether 및 chloroform으로 추출하여 회수율이 가장 높은 용매를 추출용매로 선 정하였다. 최적 $\mathrm{pH}$ 는 $\mathrm{pH}$ 1.5 9까지 산성 영역은 $\mathrm{HBr}$, 알카리 영역은 $\mathrm{KOH}$ 로 조절한 다음 브롬 유도체화 반응을 거친 후 $\mathrm{EA}$ 로 추출하고 회수율을 분석하여 최적의 $\mathrm{pH}$ 조건을 결정하였다.

결과 및 토의: 활성탄이 장착된 Supelclean ${ }^{\mathrm{TM}}$ Coconut Charcoal 카트리지가 $98.8 \%$ 회수율을 보여 본 연구의 목적 에 적합한 것으로 판단되었으며 탈착용매의 부피는 $12 \mathrm{~mL}$ 로 결정하였다. 최적의 브롬 유도체화 반응시간: 3 시간, $\mathrm{pH}: 1.5$, 추출용매: $\mathrm{EA}$ 가 가장 적합하였다. 또한 분석방법 검증 실험에서 상관계수 $\mathrm{R}^{2}$ 값이 0.9981 로서 양호한 직 선성을 나타내었다. 방법검출한계 및 정량한계는 $1.19 \mu \mathrm{g} / \mathrm{L}$ 및 $3.79 \mu \mathrm{g} / \mathrm{L}$, 일내 정확도는 $100.6 ~ 101.7 \%$ 이었으며, 정밀도는 3.2 3.5\%이었다. 일간 정확도는 95.7 97.4\%이었으며, 정밀도는 4.3 8.0\%로 나타났다. 본 연구에서 확립 된 분석방법으로 6 개의 하수종말처리장 방류수의 경우 아크릴아마이드 함량은 5월 $0.008 \sim 0.017 \mu \mathrm{g} / \mathrm{L}, 6$ 월 $0.009 \sim 0.14 \mu \mathrm{g} / \mathrm{L}, 7$ 월 N.D. 0.02 $\mu \mathrm{g} / \mathrm{L}$ 수준이었다.

결론 : SPE법을 적용하여 가스크로마그래피/질량분석법으로 환경매체 중 수질측정용 분석시료에 대해 아크릴아마 이드 분석방법을 확립한 결과는 다음과 같다. 시료 전처리 과정에서 Supelclean ${ }^{\mathrm{TM}}$ Coconut Charcoal 카트리지를 사 용함으로써, 시료의 농축이 가능하고 효과적으로 방해물질을 제거할 수 있었다. 브롬 유도체화 반응의 최적조건은 $\mathrm{pH} 1.5,4^{\circ} \mathrm{C}$ 에서 3 시간으로 나타났고 브롬 유도체화 반응 생성물의 추출용매는 $\mathrm{EA}$ 가 가장 양호하였다. 6 개의 하 수종말처리장의 방류수의 아크릴아마이드 함량은 5월 $0.008 \sim 0.017 \mu \mathrm{g} / \mathrm{L}, 6$ 월 $0.009 \sim 0.14 \mu \mathrm{g} / \mathrm{L}$ 및 7월 N.D. 0.02 $\mu \mathrm{g} / \mathrm{L}$ 수준이었다.

주제어 : 아크릴아마이드, 고체상 추출법, 방법검출한계, 정량한계, 정밀도

\section{1. 서론}

아크릴아마이드 $\left(\mathrm{CH}_{2}=\mathrm{CHCONH}_{2}\right.$, acrylamide $)$ 는 아크릴로 니트릴(acrylonitrile)로부터 합성되는 비휘발성 비닐단량체
로 분자량 $71.08 \mathrm{~g} / \mathrm{mol}$ 의 무색, 무취의 결정성 고체이다. 아 크릴아마이드는 폴리아크릴아마이드(polyacrylamide, PAM) 의 합성에 주로 사용되고 있다. PAM의 용도는 정수 시설이 나 폐수 처리 시설의 응집제, 종이 강화제, 화장품의 피부연 
화제, 윤활제 및 생화학 실험용 크로마토그래피의 겔(gel) 등에 사용된다.

또한, 식품에 존재하는 아크릴아마이드는 식품의 가공, 조리 과정 시 $120^{\circ} \mathrm{C}$ 이상의 고온에서 아미노화합물의 친핵 성 아미노기(amino group, $-\mathrm{NH}_{2}$ )와 반응성이 큰 환원당의 카보닐기(carbonyl group, $\mathrm{C}=\mathrm{O}$ )의 마이야르 반응(Maillard reaction)으로 생성되며1,2) 아크릴아마이드의 농도는 식품의 종류, 조리방법, 수분함량, 점성 및 가열시간 등에 따라 달 라지나 일반적으로 감자스낵, 비스킷, 시리얼, 초콜릿, 커피 등의 식품에서 비교적 많은 양의 아크릴아마이드가 검출된 다고 알려져 있다. ${ }^{2 \sim 4)}$

아크릴아마이드 단량체의 독성은 중추 ${ }^{5}$ 및 말초신경 질환) 을 일으킬 수 있다고 알려져 있다. 국제 암 연구소인 IARC (International Agency for Research on Center)에서는 인체에 대해 발암 가능성이 있다고 판단하여 Group $2 \mathrm{~A}$ 로 분류하고 있 다. ${ }^{7)}$ 또한 유엔식량농업기구(Food and Agriculture Organization, FAO)와 세계보건기구(World Health Organization, WHO)는 식품으로부터 인체노출량이 1일 평균 $0.3 \sim 0.8 \mu \mathrm{g} / \mathrm{kg} \mathrm{bw} / \mathrm{day}$ 라고 발표한 바 있으며, ${ }^{8)}$ 먹는물의 아크릴아마이드 허용기 준을 $\mathrm{WHO}$ 와 미국환경보호청(U.S. Environmental Protection Agency, EPA)은 $0.5 \mu \mathrm{g} / \mathrm{L}$, 유럽연합(EU)에서는 $0.1 \mu \mathrm{g} / \mathrm{L}$ 이 하로 관리하고 있다.

우리나라의 경우에도 국내 수질오염물질 중 인체 및 수 생태계에 악영향을 미칠 우려가 있는 아크릴아마이드를 환 경부령으로 2010년 특정수질유해물질"로 추가 지정하고 배출허용기준을 신설하였다. 아크릴아마이드의 폐수배출시 설의 배출허용기준은 “청정지역" $0.015 \mathrm{mg} / \mathrm{L}$, "가와 나지역" $0.04 \mathrm{mg} / \mathrm{L}$ 로 설정하였다.

이와 같이 아크릴아마이드에 대한 관심이 높아지면서 국 외에서는 식품, 먹는 물을 비롯한 수질 및 작업장 내 공기 등과 같은 다양한 매체에서 아크릴아마이드 관련 연구가 수행되고 있다.

국내에서는 2009년 수질유해물질 적정관리를 위한 배출 허용기준 설정 연구에서 아크릴아미이드는 12 개 종말처리 장 중 5 개 종말처리장 유출수에서 LC-MS/MS로 분석한 결 과 $0.1 \sim 0.4 \mu \mathrm{g} / \mathrm{L}$ 검출되어 인체건강과 수생생물보전에 위 해를 줄 우려가 있다는 보고 ${ }^{10)}$ 와 2010년 수계별 유해물질 데이터베이스 구축 연구에서 한강수계 중량천 시료에서 $\mathrm{GC} / \mathrm{ECD}$ 를 이용하여 분석한 결과 $0.0025 \mu \mathrm{g} / \mathrm{L}$ 검출되었다 는 사례가 있다. ${ }^{11)}$

가열 식품 중에 마이야르 반응(Maillard reaction)으로 생성 된 아크릴아마이드가 함유된 음식물 쓰레기와 폴리머 (porymer)의 생산 과정과 여러 산업 활동에서 이용되는 PAM 에서 단량체로 방출되는 아크릴아마이드는 환경에 유입되어 인체 및 생태계에 악영향을 초래할 수 있다. 이러한 아크릴아 마이드를 검출하기 위한 기기분석법으로는 $\mathrm{GC},{ }^{12,13)} \mathrm{HPLC},{ }^{14)}$
$\mathrm{GC} / \mathrm{MS}^{14-17)} \mathrm{GC} / \mathrm{MS} / \mathrm{MS},{ }^{18,19)} \mathrm{LC} / \mathrm{MS}^{1} \mathrm{MS}^{3,20,21)}$ 등 다양한 분 석기기를 이용한 분석법이 주로 사용되고 있다. LC/MS/MS를 이용하여 분석하는 것이 가장 빠르고 효율적인 방법인 것으 로 알려져 있으며, 이 방법은 신속한 전처리 과정을 거쳐 빠르 게 분석할 수 있는 장점이 있으나 고가의 장비로 많은 실험실 에 보편화되어 있지 않은 단점이 있다.

수질공정시험기준 ES 04609.122)에 제시되어 있는 아크릴 아마이드 분석은 복잡한 간섭물질을 제거하지 않고 많은 양의 시료를 유도체화 하여 분석하고 있다. 이 경우 추출 시 용매의 에멀젼화 등으로 정확한 분석이 되지 않는다. 정 제는 브롬화 반응이 끝난 후 수행하도록 제시하고 있어 불 완전한 정제가 될 우려가 있다. 내부표준물질도 기기분석 바로 전 시료에 첨가하게 되어 있어 전처리과정 중 일어나 는 실험에 대한 오차를 보상할 수 없는 등 미진한 부분과 정량한계가 높은 것이 문제점으로 지적된다.

따라서 본 연구는 국내의 수질측정용 시료에서 처음 시도 된 분석방법으로 실험실에서 범용적으로 사용되는 $\mathrm{GC} / \mathrm{MS}$ 를 이용하여 물 시료 중 추출과 정제를 동시에 할 수 있는 새로운 SPE법을 적용하고, 브롬 유도체화 반응의 최적화를 통하여 특정수질유해물질로 알려진 아크릴아마이드 분석 의 최적조건을 확립하기 위하여 수행되었으며, 정립된 방 법에 의하여 대전, 충남·북 지역의 하수종말처리장 6 곳의 유입·방류수를 대상으로 아크릴아마이드를 $\mathrm{GC} / \mathrm{MS}$ 로 분석 하였다.

\section{2. 재료 및 방법}

\section{1. 시약 및 기구}

아크릴아마이드 표준품과 내부표준물질 $\mathrm{AA}-\mathrm{d}_{3}$ 은 Sigma사 제품을 사용하였다. 표준 시약의 농도는 $2.5 \mu \mathrm{g} / \mathrm{L} 100 \mu \mathrm{g} / \mathrm{L}$ 의 농도를 조제하여 검량곡선 작성용 시료로 하였다. 내부 표준물질의 농도는 $0.35 \mu \mathrm{g} / \mathrm{L}$ 로 조제하여 사용하였다. 실험 과정 중 사용한 유기용매 메탄올, EA 및 DCM은 Wako사, chloroform은 대정화금(주)사, diethyl ether는 Showa사의 잔 류 농약 분석용(PRA급)을 사용하였다. 브롬 유도체화 시약 인 potassium bromide $(\mathrm{KBr})$, hydrobromic acid $(\mathrm{HBr})$ 및 bromine $\left(\mathrm{Br}_{2}\right)$ 은 Junsei사 제품을 그 외 $\mathrm{Na}_{2} \mathrm{~S}_{2} \mathrm{O}_{3}, \mathrm{Nacl}$, $\mathrm{Na}_{2} \mathrm{SO}_{4}$ 는 Wako사 제품을 사용하였다. SPE장치는 Supelco 의 Visiprep ${ }^{\mathrm{TM}} \mathrm{SPE}$ Vacuum manifold를 사용하였으며, 불순 물 정제를 위한 SPE cartridge는 Supelclean ${ }^{\mathrm{TM}}$ Coconut Charcoal SPE cartridge $(2 \mathrm{~g}, 6 \mathrm{cc})$, Supelclean ${ }^{\mathrm{TM}} \mathrm{ENVI}^{\mathrm{TM}}$ Carb SPE cartridge $(0.25 \mathrm{~g}, 6 \mathrm{~mL})$ 는 Supelco, Cleanert ${ }^{\circledR}$ ODS C18 (500 mg, $6 \mathrm{~mL}$ )는 Agela Technologies, Oasis HLB SPE Cartridges $(200 \mathrm{mg}, 6 \mathrm{cc})$ 는 Waters사에서 구입하여 사용하였 다. 분석 장비는 Agilent $6890 \mathrm{~N} \mathrm{GC/5973} \mathrm{MSD}$ 을 사용하여 선 택적 이온모니터링 분석법인 SIM (Selected Ion Monitoring) 
Table 1. Chemical structure and physicochemical characteristics of acrylamide.

$\begin{array}{cccccc}\text { Compound } & \begin{array}{c}\text { Molecular } \\ \text { Weight }\end{array} & \begin{array}{c}\text { Chemical } \\ \text { Structure }\end{array} & \begin{array}{c}\text { Molecular } \\ \text { Formula }\end{array} & \begin{array}{c}\text { Vapor pressure } \\ \left(20^{\circ} \mathrm{C}\right)\end{array} & \begin{array}{c}\text { Solubility in water } \\ \left(20^{\circ} \mathrm{C}\right)\end{array} \\ \text { Acrylamide } & \begin{array}{c}71.08 \\ \mathrm{~g} / \mathrm{mol}\end{array} & & \end{array}$

${ }^{*}$ n-Octanol/Water Partition Coefficient

Table 2. Description of the 6 surveyed sewage treatment plants (STPs).

\begin{tabular}{ccccc} 
STPs & Capacity $\left(\mathrm{m}^{3} /\right.$ day $)$ & Process & Source & Effiluent \\
A & 168,200 & Denipho & domestic sewage, livestock wastewater & tributary \\
B & 268,600 & ACS & domestic sewage, industrial wastewater & tributary \\
C & 280,000 & HANT & domestic sewage, industrial wastewater & tributary \\
D & 18,000 & Denipho & domestic sewage & tributary \\
E & 62,390 & KSMBR & domestic sewage, feces and urine & tributary \\
F & 900,000 & PSBR & domestic sewage, feces and urine & tributary \\
\hline
\end{tabular}

모드를 이용하였고, 컬럼은 DB-5MS plus $(30 \mathrm{~m} \times 0.25 \mathrm{~mm}$ $\mathrm{ID} \times 0.25 \mu \mathrm{m}$ Film thickness)를 이용하여 분석을 수행하였 다. 본 실험에 사용한 아크릴아마이드의 특성은 Table 1과 같다. $^{23)}$

\section{2. 시료 채수}

본 연구에 사용된 시료는 하수종말처리장 중 대전 및 충 남·북 지역에 위치한 6 개의 하수종말처리장을 조사대상으 로 선정하였다. 하수종말처리장별 처리공법 및 시설용량 등은 Table 2와 같다. 하수종말처리장의 주요 처리 공법은 Denipho, ACS (ASRT Control System), HANT (Hyun Dai Advanced Nutrients Treatment), KSMBR (Kowaco-KMSSsang-young Membrane Bio-Reactor), PSBR (Pumyang Sequencing Batch Reactor)이었다. 아크릴아마이드 분석을 위한 시료는 수질오염공정시험기준 ES 04130.1c에 따라 채 취하였다. 채취한 시료는 $4^{\circ} \mathrm{C}$ 이하의 냉암소에 보관하고 아크릴아마이드 분석은 채취일로부터 48 시간 이내에 수행 하였다.

\section{3. 시료의 전처리}

\subsection{1. 고체상추출(SPE)법}

채수된 시료는 입자상 물질의 제거를 위하여 유리섬유 여과지(GF/C Filter, $1.2 \mathrm{um}, \varnothing 47 \mathrm{~mm}$, Whatman)로 여과하 였다. 여과된 시료 $250 \mathrm{~mL}$ 에 내부표준용액 $\mathrm{AA}-\mathrm{d}_{3}(0.35$ $\mu \mathrm{g} / \mathrm{L}) 1 \mathrm{~mL}$ 를 가한 후 SPE법을 이용하여 시료를 정제하였 다. 정제는 진공매니폴드에 Supelclean ${ }^{\mathrm{TM}}$ Coconut Charcoal $\mathrm{SPE}$ 카트리지를 장착한 후 미리 methanol $5 \mathrm{~mL}$, 정제수 5
$\mathrm{mL}$ 를 차례로 통과시켜 카트리지 내의 active carbon을 활 성화한 다음 시료를 $3 \mathrm{~mL} / \mathrm{min}$ 의 속도로 주입하여 시료 중 $\mathrm{AA}$ 를 흡착시켰다. 시료의 주입이 끝난 카트리지는 약 15 분간 진공 감압펌프를 이용하여 건조한 다음 메탄올 12 $\mathrm{mL}$ 로 아크릴아마이드를 용리시켜 브롬 유도체화 반응 시 료로 사용하였다.

\subsection{2. 브롬 유도체화 반응}

EPA method $8032 \mathrm{~A}^{24)}$ 를 약간 변형하여 카트리지에서 용 출된 추출액에 $\mathrm{KBr} 7.0 \mathrm{~g}$ 을 넣고 희석한 $\mathrm{HBr}$ 를 이용하여 $\mathrm{pH} 1.5$ 로 조절한 다음 포화 브롬수 $3 \mathrm{~mL}$ 를 첨가한 후 알 루미늄 호일로 싸서 $4{ }^{\circ} \mathrm{C}$ 냉장고에서 3 시간 동안 브롬 유도 체화 반응을 시켰다. 브롬 유도체화 반응 후 $1 \mathrm{M} \mathrm{Na}_{2} \mathrm{~S}_{2} \mathrm{O}_{3}$ 수적을 가하여 남아있는 브롬을 제거하였다. 염석 시약으 로 Nacl $5 \mathrm{~g}$ 을 넣고 브롬화 반응 생성물인 2,3-DBPA를 에 틸아세테이트 $25 \mathrm{~mL}$ 로 2회 반복하여 추출하였다. 수분을 제거하기 위하여 무수 $\mathrm{Na}_{2} \mathrm{SO}_{4}$ 을 가한 다음 회전감압농축 기로 완전히 증발시킨 후 에틸아세테이트 $2 \mathrm{~mL}$ 를 가하여 녹인 후 $1 \mu \mathrm{L}$ 를 $\mathrm{GC} / \mathrm{MS}$ 에 주입하여 분석하였다. 시료 전 처리 과정은 Fig.1에 나타내었다.

\section{4. $\mathrm{GC} / \mathrm{MS}$ 의 분석조건}

본 연구에 사용된 분석기기는 Agilent $6890 \mathrm{~N} \mathrm{GC/5973}$ $\mathrm{MSD}$ 이며, $\mathrm{SIM}$ 모드로 정량 분석하였다. 정량분석에 사용 한 2,3-DBPA의 mass fragment ion은 m/z 150 및 $\mathrm{m} / \mathrm{z} 152$ 을 사용하였고, $\mathrm{AA}-\mathrm{d}_{3}$ 의 브롬 유도체 $\mathrm{D}_{3}-2,3-\mathrm{DBPA}$ 의 mass fragment ion은 $\mathrm{m} / \mathrm{z} 155$ 를 사용하였다. $\mathrm{GC} / \mathrm{MS}$ 의 분석조건 은 Table 3과 같다. 


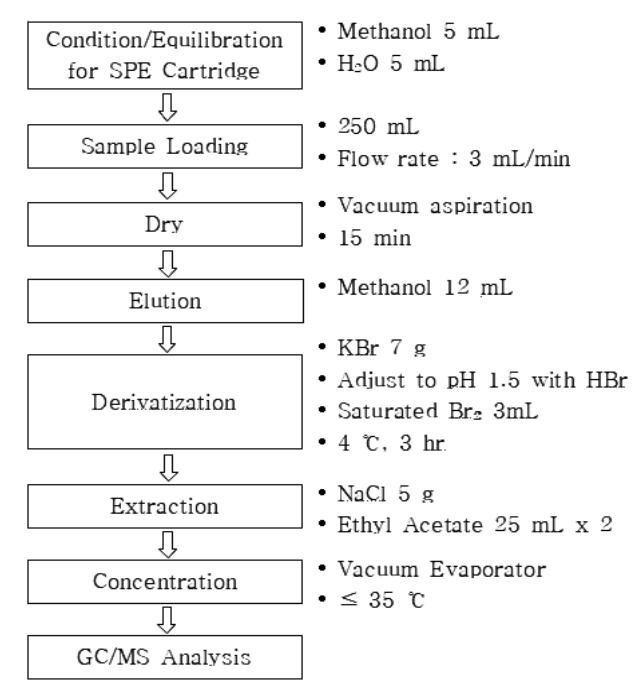

Fig. 1. Flowchart depicting sample preparation and analysis.

Table 3. GC/MS operating conditions for the determination of acrylamide.

\begin{tabular}{cc} 
Instrument & Aglient $6890 \mathrm{~N} \mathrm{GC} / 5973 \mathrm{MSD}$ \\
Column & DB-5MS plus $(30 \mathrm{~m} \times 0.25 \mathrm{~mm} \times 0.25 \mu \mathrm{m})$ \\
Carrier gas (Flow rate) & $\mathrm{He}(1.0 \mathrm{~mL} / \mathrm{min})$ \\
Oven temperature & $75^{\circ} \mathrm{C}(5 \mathrm{~min}) \rightarrow 10^{\circ} \mathrm{C} / \mathrm{min} \rightarrow 180^{\circ} \mathrm{C}(2 \mathrm{~min})$ \\
Injector temperature & $240^{\circ} \mathrm{C}$ \\
Transfer line temp & $230^{\circ} \mathrm{C}$ \\
Ionization mode & $\mathrm{EI}, 70 \mathrm{eV}$ \\
Detection & $\mathrm{SIM} \mathrm{mode}$ \\
Injection volume & $1 \mu \mathrm{L}$ \\
Injection mode & Pulse splitless \\
\hline
\end{tabular}

\section{3. 결과 및 고찰}

\section{1. 고체상추출(SPE)흡착제 선정}

매트릭스가 복잡한 시료에서 분석물질을 검출하기 위해서 는 분석물질의 농축이 용이하고 비교적 정제가 쉬운 SPE법 이 많이 사용된다. ${ }^{25}$ 본 연구에 사용된 고체상추출 카트리지 는 특성에 따라 선정하여 사용하였다. 활성탄으로 이루어진 Supelclean ${ }^{\mathrm{TM}}$ Coconut Charcoal 카트리지, 탄소가 주성분이 나 공극이 없는 흑연으로 제조된 Supelclean ${ }^{\mathrm{TM}} \mathrm{ENVI}^{\mathrm{TM}}-$ Carb 카트리지, 탄소입자가 부착된 실리카기반의 물질로 주 로 소수성 물질의 분석에 쓰이는 Cleanert ODS C18, 소수성 과 친수성의 특성을 함께 가지는 Oasis HLB Extraction 카트 리지의 4종을 이용하여 회수율을 실험하였다. 정제수 100 $\mathrm{mL}$ 에 아크릴아마이드 표준용액 $(50 \mu \mathrm{gL})$ 과 내부표준물질 $(0.35 \mu \mathrm{g} / \mathrm{L})$ 을 가하고 2.3 .1 의 고체상추출(SPE)법과 2.3.2의 브롬 유도체화 방법으로 실험한 결과는 Table4와 같다. 표 에서 보는 바와 같이 Supelclean ${ }^{\mathrm{TM}}$ Coconut Charcoal은 회수 율이 $98.8 \%$, Supelclean ${ }^{\mathrm{TM}} \mathrm{ENVI}^{\mathrm{TM}}{ }_{-}$Carb는 $5.0 \%$, Cleanert
Table 4. Recovery of acrylamide in different SPE cartridge species.

\begin{tabular}{lcccc} 
& $\begin{array}{c}\text { Oasis } \\
\text { HLB }\end{array}$ & $\begin{array}{c}\text { ENVI }^{\text {TM }} \\
\text {-Carb }^{2}\end{array}$ & $\begin{array}{c}\text { Supeldean }^{\mathrm{TM}} \\
\text { Coconut Charcoal }\end{array}$ & $\begin{array}{c}\text { Cleanert } \\
\text { SC18 }\end{array}$ \\
Recovery (\%) & 13.9 & 5.0 & 98.8 & 17.4 \\
\hline
\end{tabular}

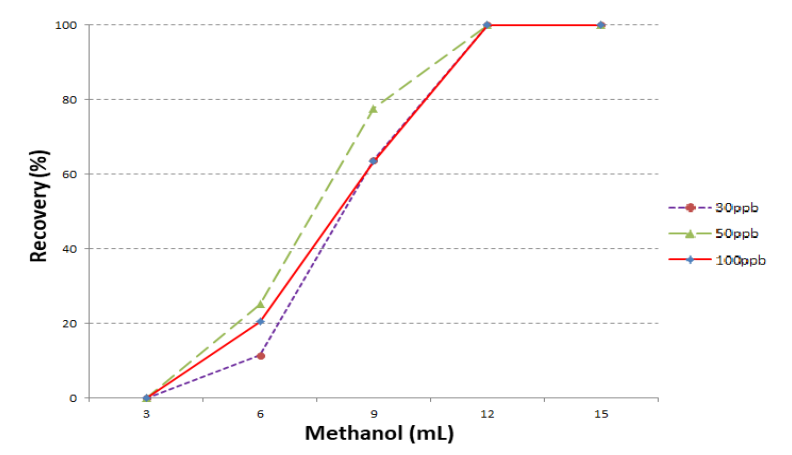

Fig. 2. The effect of elution volume on the recovery of acrylamide.

ODS C18는 17.4\% 및 Oasis HLB는 13.9\%로 나타났다. 따라 서 Supelclean ${ }^{\mathrm{TM}}$ Coconut Charcoal 카트리지가 본 연구 목적 에 적합한 것으로 판단되었다. 이와 같은 결과는 Coconut Charcoal 카트리지가 다공성이며, 표면적이 넓은 활성탄으 로 구성되어 있고, 활성탄에 친수성이며 극성이 큰 아크릴 아마이드가 흡착하는 성질로 보인다. ${ }^{19)}$ 이후 시료 전처리 시 사용할 SPE는 Supelclean ${ }^{\mathrm{TM}}$ Coconut Charcoal 카트리지로 선정하였다.

\section{2. 최적 탈착용매의 부피}

Coconut Charcoal 카트리지에 흡착된 아크릴아마이드에 대해 탈착 용매량를 선정하기 위한 실험을 수행하였다. 정제 수 $100 \mathrm{~mL}$ 에 AA 농도가 다른 $30 \mu \mathrm{g} / \mathrm{L}, 50 \mu \mathrm{g} / \mathrm{L}$ 및 $100 \mu \mathrm{g} / \mathrm{L}$ 인 표준용액 $2 \mathrm{~mL}$ 와 내부표준물질 $(0.35 \mu \mathrm{g} / \mathrm{L}) 1 \mathrm{~mL}$ 를 첨가 하고 시료의 전처리와 동일한 방법으로 Coconut Charcoal 카 트리지에 통과시켰다. 흡착된 아크릴아마이드는 메탄올을 사용하여 $3 \mathrm{~mL}$ 씩 용출액을 받아 브롬 유도체화 반응 후 생 성된 2,3-DBPA를 $\mathrm{GC} / \mathrm{MS}$ 로 회수율을 분석한 결과는 Fig. 2 와 같다. Fig.2에서 보는 바와 같이 농도가 다른 세 수준의 아크릴아마이드 용출 부피는 $12 \mathrm{~mL}$ 에서 완전히 용출되는 것으로 나타났다. 이와 같은 결과는 Feng et al. ${ }^{26}$ 이 activated carbon 카트리지를 이용하여 아크릴아마이드를 용출할 때 메탄올이 $10 \mathrm{~mL}$ 이상에서는 더 이상 아크릴아마이드가 용 출되지 않았다는 보고와 유사한 경향을 나타내었다. 이후 실 험은 아크릴아마이드의 탈착은 메탄올 $12 \mathrm{~mL}$ 로 하였다.

\section{3. 브롬 유도체화 반응의 최적화}

\subsection{1. 반응시간}

아크릴아마이드 유도체화 반응의 최적 시간을 알아보기 


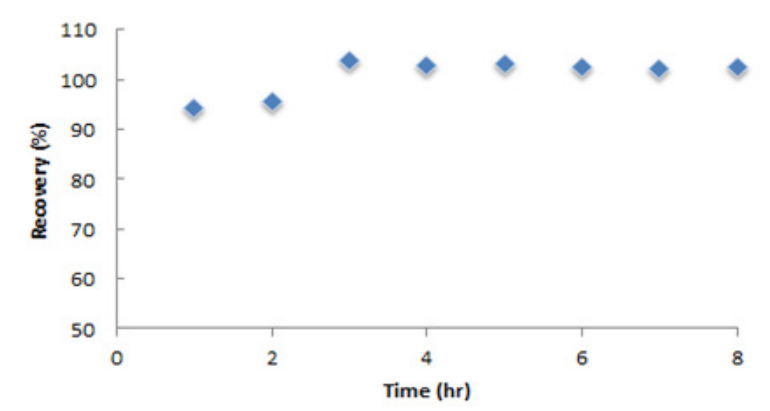

Fig. 3. Effect of the reaction time on the bromination process acrylamide. The study was conducted with $100 \mathrm{~mL}$ water samples containing $50 \mu \mathrm{g} / \mathrm{L} \mathrm{AA}$ and $0.35 \mu \mathrm{g} / \mathrm{L}$ IS $\left(A A-d_{3}\right)$. The bromination was conducted under the condition of $\mathrm{pH} 1.5$ and temperature of $4^{\circ} \mathrm{C}$.

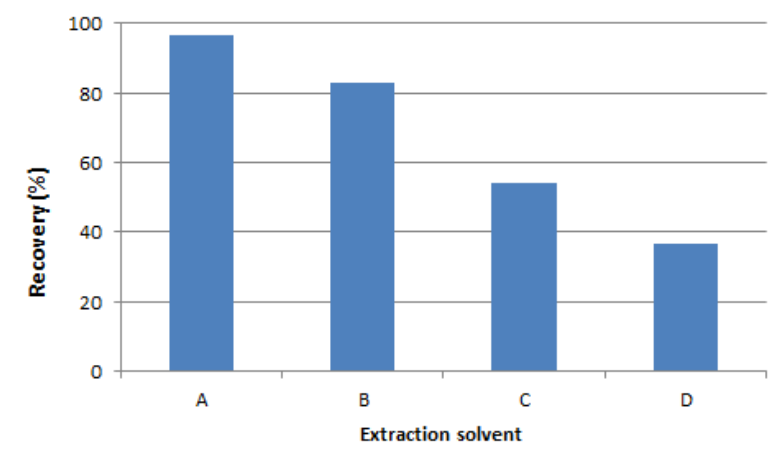

Fig. 4. Efficiency of extraction solvent of AA-derivatives from bromination. The study was conducted with $100 \mathrm{~mL}$ water samples containing $50 \mu \mathrm{g} / \mathrm{L} \mathrm{AA}$ and $0.35 \mu \mathrm{g} / \mathrm{L}$ IS $\left(A A-d_{3}\right)$. The bromination was conducted under the condition of $\mathrm{pH} 1.5$ and reaction time of $3 \mathrm{~h}$. at $4{ }^{\circ} \mathrm{C}$. The extraction was performed twice $(2 x)$ with each solvent $(25 \mathrm{~mL})$. (A: EA, B: DCM, C: Diethyl ether, D: Chloroform).

위한 실험을 수행하였다. 정제수 $100 \mathrm{~mL}$ 에 아크릴아마이 드 농도가 $50 \mu \mathrm{g} / \mathrm{L}$ 인 표준용액 $2 \mathrm{~mL}$ 와 내부표준물질 $(0.35$ $\mu \mathrm{g} / \mathrm{L}) 1 \mathrm{~mL}$ 를 첨가하여 시료로 하였다. $\mathrm{pH}$ 를 1.5 로 조절한 후 시료 전처리와 같은 방법으로 $4^{\circ} \mathrm{C}$ 에서 유도체화 반응을 진행시키면서 1 시간마다 시료를 채취하여 회수율을 분석 한 결과를 Fig.3에 나타내었다. Fig.3에서 보는 바와 같이 3 시간 후에 회수율이 $103.9 \%$ 로 완전한 반응이 종료된 것 으로 나타났다. 아크릴아마이드의 반응시간에 대한 연구는 $4^{\circ} \mathrm{C}$ 에서 15 시간, ${ }^{27)} 4^{\circ} \mathrm{C}$ 에서 24 시간 ${ }^{28)}$ 및 $0^{\circ} \mathrm{C}$ 에서 24 시간 ${ }^{29)}$ 등으로 다양한 것은 이때 사용한 내부표준물의 다양성 때 문이라고 했다. 일반적으로 동위원소 처리된 표준품의 반 응시간이 짧다고 하며 ${ }^{21}$ 이후 브롬 유도체화 반응시간 3 시 간으로 선정하였다.

\subsection{2. 추출용매}

$\mathrm{AA}$ 를 브롬으로 치환하여 생성된 2,3-DBPA를 효과적으 로 추출하기 위한 추출용매에 대해 실험을 수행하였다. 실

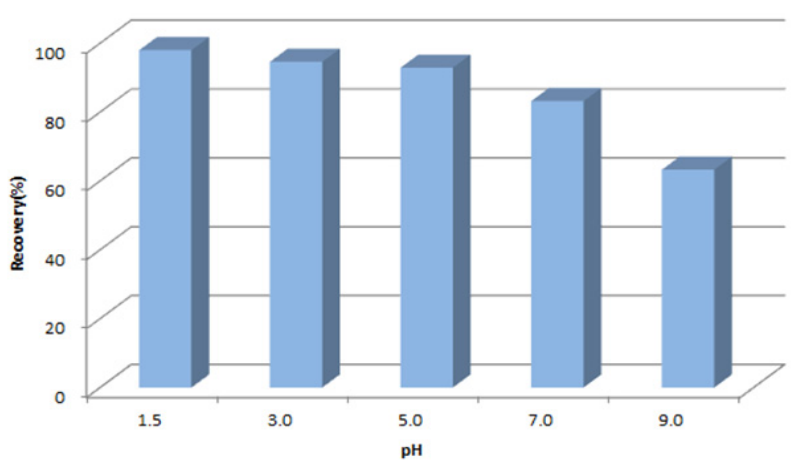

Fig. 5. Effect of $\mathrm{pH}$ on the bromination reaction of acryamide.

험에 사용된 용매는 chloroform, diethyl ether, DCM 및 EA 등 용매의 극성 차이에 따라 선정하였다. 브롬 유도체화 반 응시간 $(3 \mathrm{~h})$ 이 끝난 후 선정된 각 용매로 2,3-DBPA를 추출 하여 회수율을 분석한 결과는 Fig. 4와 같다. 그림에서 보 는 바와 같이 2,3-DBPA의 회수율은 $\mathrm{EA}$ 가 $97.7 \%$ 로 가장 높게 나타나 본 연구에서 추출용매로 사용하기에 적당한 용매로 선정하였다. 이와 같이 $\mathrm{EA}$ 가 추출율이 높은 것은 2,3-DBPA가 EA에 추출되기 적당한 극성으로 변화하였기 때문이라고 보고된바 있다. ${ }^{14)}$ 따라서 이후 시험에서는 EA 를 추출용매로 사용하여 분석하였다.

\subsection{3. $\mathrm{pH}$ 의 영향}

브롬 유도체화 반응에서 최적 $\mathrm{pH}$ 의 알아보기 위한 시험을 수행하였다. 정제수 $100 \mathrm{ml}$ 에 아크릴아마이드 농도가 50 $\mu \mathrm{g} / \mathrm{L}$ 인 표준용액 $2 \mathrm{ml}$ 와 내부표준물질 $0.35 \mu \mathrm{g} / \mathrm{L} 1 \mathrm{~mL}$ 를 첨가한 후 $\mathrm{pH}$ 1.5 9까지 산성 영역은 $\mathrm{HBr}$, 알칼리 영역은 $\mathrm{KOH}$ 로 조절하였다. 브롬 유도체화 반응을 거친 후 $\mathrm{EA}$ 로 추출하고 농축하여 회수율을 분석한 결과 Fig. $\mathbf{5}$ 와 같다. Fig.5에서 보는 바와 같이 $\mathrm{pH} 1.5$ 에서 회수율이 $98.0 \%$ 로 가 장 높게 나타났으며, $\mathrm{pH}$ 가 알칼리 영역으로 갈수록 회수율 저조하게 나타났다. 이와 같은 결과는 아크릴아마이드는 산 성 상태에서 안정하다는 보고 ${ }^{14}$ 와 그 외 아크릴아마이드의 브롬 유도체화 반응을 산성 상태 또는 $\mathrm{pH}$ 1 3에서 실험하였 다는 보고 ${ }^{18,19)}$ 와 비슷한 양상을 보였다.

\section{4. 방해물질 제거 효과}

매트릭스가 복잡한 물 시료에서 아크릴아마이드를 분석 할 때 고체상추출법의 효과를 알아보기 위하여 실험을 수 행한 결과는 Fig.6과 같다. Fig.6에서 보는 바와 같이 고상 추출법을 수행하였을 경우 TIC (Total ion chromatogram) 상에서 불순물 피크가 감소하는 것을 확인할 수 있었다. 불 순물 피크가 많으면 기기분석 시 방해효과로 작용되며, 방 해물질을 적절하게 제거하지 않을 경우, 휘발하지 않는 방 해물질들은 $\mathrm{GC}$ 의 주입구나 컬럼에 머무르게 되며 이를 통 하여 분석물들이 이동하는 과정에서 환원 및 변형이 이루 
Table 5. Linear equation, method detection limit (MDL) and limit of quantitation (LOQ) of acrylamide.

\begin{tabular}{|c|c|c|c|c|c|}
\hline Compound & $\begin{array}{l}\text { Range } \\
\text { ( } \mu / L / L)\end{array}$ & Calibration curve & $R^{2}$ & $\begin{array}{c}\text { MDL } \\
(\mu g / L)\end{array}$ & $\begin{array}{c}100 \\
(\mu g / L)\end{array}$ \\
\hline Acrylamide & $2.5 \sim 100$ & $0.0376 x-0.0368$ & 0.9981 & 1.19 & 3.79 \\
\hline
\end{tabular}

Table 6. Intraday and interday laboratory accuracy and precision results for the analysis of acrylamide $(n=3)$.

\begin{tabular}{c|ccccccc} 
Spiked & \multicolumn{3}{c}{ Intra-day Measured value } & & \multicolumn{3}{c}{ Inter-day Measured value } \\
$\begin{array}{c}\text { Conc. } \\
(\mu \mathrm{g} / \mathrm{L})\end{array}$ & $\begin{array}{c}\text { Mean } \pm \text { SD } \\
(\mu \mathrm{g} / \mathrm{L})\end{array}$ & $\begin{array}{c}\text { Accuracy } \\
(\%)\end{array}$ & $\begin{array}{c}\text { Precision } \\
(\%)\end{array}$ & & $\begin{array}{c}\text { Mean } \pm S D \\
(\mu \mathrm{g} / \mathrm{L})\end{array}$ & $\begin{array}{c}\text { Accuracy } \\
(\%)\end{array}$ & $\begin{array}{c}\text { Precision } \\
(\%)\end{array}$ \\
\hline 10 & $10.2 \pm 0.35$ & 102.0 & 3.5 & & $9.6 \pm 0.76$ & 96.0 & 8.0 \\
\hline 50 & $50.3 \pm 1.60$ & 100.6 & 3.2 & & $48.7 \pm 2.12$ & 97.4 & 4.3 \\
\hline
\end{tabular}

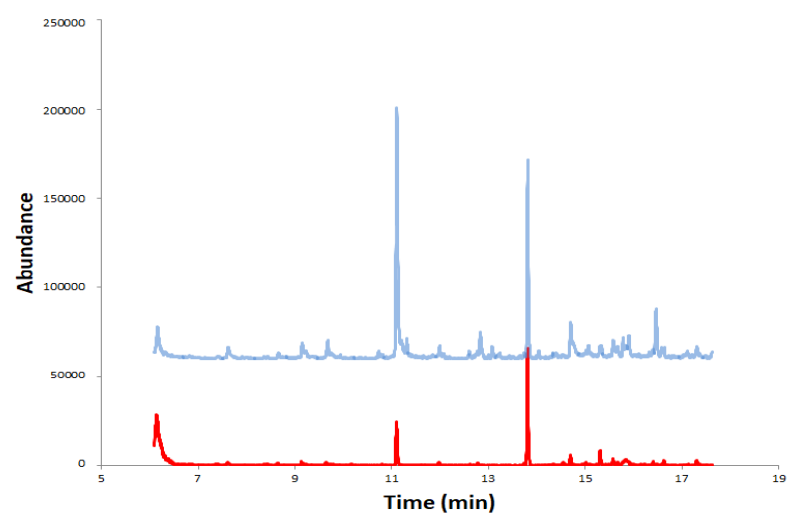

Fig. 6. Comparison of matrix interference in the water sample with SPE (red color) and without SPE (green color) treatment. The analytical column was a $30 \mathrm{~m} \mathrm{DB}-5 \mathrm{MS}$ plus column ( $0.25 \mathrm{~mm}$ I.D. $\times 0.25 \mu \mathrm{m}$ F.T). The flow rate of helium as a carrier gas was $1.0 \mathrm{~mL} / \mathrm{min}$. The injector temperature was set at $240^{\circ} \mathrm{C}$. The oven temperature program began at $75^{\circ} \mathrm{C}$, raised to $180^{\circ} \mathrm{C}$ at $10^{\circ} \mathrm{C} / \mathrm{min}$. Full-scan mass spectra: m/z 45 650.

어지게 된다. ${ }^{30,31)}$ 따라서 정확한 분석을 위하여 시료의 불 순물 제거에 반드시 고체상추출법이 필요하며, 기기 유지, 관리면서도 유리할 것으로 판단된다.

\section{5. 분석방법의 검증}

분석방법의 검증은 수질오염공정기준에 따라 수행하였 다. 직선성은 아크릴아마이드 표준용액 2.5 100 $\mu \mathrm{g} / \mathrm{L}$ 농도 를 조제하여 2.3.1 및 2.3.2 방법으로 실험을 진행하였다. 아크릴아마이드 유도체 $(\mathrm{m} / \mathrm{z}: 150, \mathrm{~m} / \mathrm{z}: 152)$ 피크와 내부 표준물질 $(\mathrm{m} / \mathrm{z} 155)$ 피크의 면적비 $\left[\mathrm{A}_{\mathrm{S}} / \mathrm{A}_{\mathrm{IS}}\right]$ 를 $\mathrm{Y}$ 축으로 하고 농도를 $\mathrm{X}$ 축으로 하여 검량곡선을 작성한 결과를 Table 5 에 나타냈다. Table 5에서 보는 바와 같이 상관계수 값이 0.9981 로서 양호한 직선성을 나타내었다.

$\mathrm{MDL}$ 및 $\mathrm{LOQ}$ 는 수질공정시험기준에 따라 검량곡선에서 가장 낮은 농도인 $2.5 \mu \mathrm{g} / \mathrm{L}$ 에 대한 7회 반복 평가를 통해 표준편차를 구하고 표준편차의 3.14 배 값을 $\mathrm{MDL}, 10$ 배 값 을 $\mathrm{LOQ}$ 로 결정하였다. 이 방법으로 계산하여 확인한 결과
방법검출한계와 정량한계는 각각 $1.19 \mu \mathrm{g} / \mathrm{L}$ 및 $3.79 \mu \mathrm{g} / \mathrm{L}$ 으로 나타나 수질오염공정기준에서 제시하는 정량한계 $5 \mu \mathrm{g} / \mathrm{L}$ 보다 낮았다. GC-Ion trap-MS로 중국식품을 분석하여 정 량한계가 $10 \mu \mathrm{g} / \mathrm{L}^{28)}$ 이였다는 보고와 biscuits를 시료로 bromination 후 $\mathrm{GC} / \mathrm{MS} / \mathrm{MS}$ 로 분석한 결과의 정량한계 $13.89 \mu \mathrm{g} / \mathrm{L}^{18)}$ 보다 더 낮은 정량한계를 나타냈다. 정확도 및 정밀도는 일내(intra-day)와 일간(inter-day)으로 구분하여 일 내는 동일한 날에 2 가지 농도를 각각 3 반복으로 실시하였 으며, 일간은 서로 다른 날짜에 3 일 동안 실시하여 회수율 을 분석한 결과는 Table 6과 같다.

$10 \mu \mathrm{g} / \mathrm{L}$ 및 $50 \mu \mathrm{g} / \mathrm{L}$ 의 표준용액을 시료 전처리와 동일한 방법으로 진행하여 하루에 반복적인 분석을 3 회 실시하여 측정된 일내 정확도는 $100.6 \sim 102.0 \%$ 이었으며, 정밀도는 $3.2 \sim 3.5 \%$ 이었다. 또한 3 일 동안 반복적인 실험을 실시하여 분석된 일간 정확도는 96.0 97.4\%, 정밀도는 4.3 8.0\%로 나타났다. Table 7은 환경매체 중 다양한 수질측정용 시료 에 대해 아크릴아마이드의 분석방법과 본 연구와 비교하여 나타내었다.

\section{6. 실제 시료 분석}

본 연구에서 확립된 분석방법으로 실제 시료에 적용하기 위하여 하수종말처리장의 유입수와 방류수에 대하여 수질 특정유해물질로 알려진 아크릴아마이드 검출현황을 파악 하였다. 2019년 5월, 6월 및 7월에 채수하여 분석한 6개 하 수종말처리장에서 검출된 아크릴아마이드 함량을 Fig.7 및 Fig. 8에 나타내었다. 3 차에 걸쳐 분석한 결과, 유입수에서 5월에는 0.03 3.47 $\mu \mathrm{g} / \mathrm{L}, 6$ 월에는 0.02 0.26 $\mu \mathrm{g} / \mathrm{L}, 7$ 월에는 $0.04 \sim 0.15 \mu \mathrm{g} / \mathrm{L}$ 의 농도 범위로 검출되었고, 방류수의 경우 5월에는 0.008 0.017 $\mu \mathrm{g} / \mathrm{L}, 6$ 월에는 0.009 0.14 $\mu \mathrm{g} / \mathrm{L}$, 7월 에는 불검출 $0.02 \mu \mathrm{g} / \mathrm{L}$ 의 농도법위로 검출되었다. 이와 같 은 결과는 환경과학원의 2009년 수질유해물질 적정관리를 위한 배출허용기준 설정 연구에서 아크릴아미이드가 종말 처리장 유출수에서 $0.1 \sim 0.4 \mu \mathrm{g} / \mathrm{L}$ 검출되었다는 보고 ${ }^{10)}$ 보다 상당히 낮은 함량을 나타내었고, 2010년 수계별 유해물질 
Table 7. Comparison of analytical methods for acrylamide determination.

\begin{tabular}{|c|c|c|c|c|c|}
\hline Reference & Matrix & $\begin{array}{c}\text { SPE } \\
\text { sorbent }\end{array}$ & $\begin{array}{c}\text { Derivatization } \\
\text { reagent }\end{array}$ & $\begin{array}{l}\text { Desorption } \\
\text { solvent }\end{array}$ & Measurement \\
\hline 25 & Ground, river water & Active carbon & no & Acetone & GC/MS \\
\hline 24 & Water & no & $\mathrm{Br}_{2}$ & - & GC-ECD \\
\hline 39 & Surface, drinking water & no & Xanthydrol & - & GC/MS \\
\hline 40 & Drinking water & Active carbon & no & Acetone & GC/MS \\
\hline 32 & $\begin{array}{l}\text { WWTP* Pit water } \\
\text { Produced water }\end{array}$ & Active carbon & no & Methanol & LC/MS/MS \\
\hline 38 & Drinking water & Active carbon & no & Methanol & LC/MS/MS \\
\hline 26 & River water & Active carbon & no & Methanol & LC/MS/MS \\
\hline This study & STP $^{* *}$ & Active carbon & $\mathrm{Br}_{2}$ & Methanol & GC/MS \\
\hline
\end{tabular}

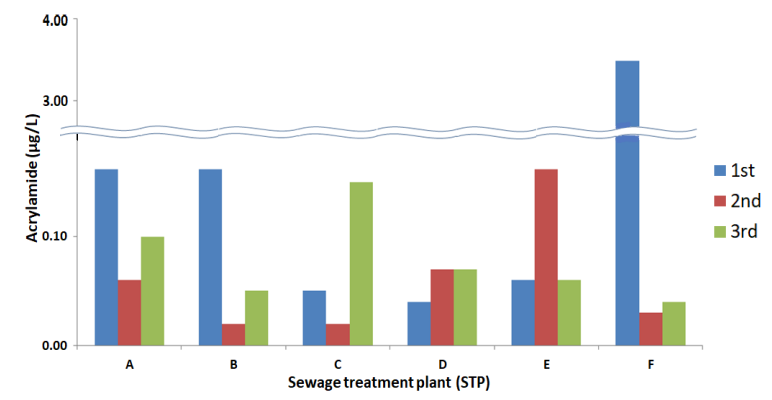

Fig. 7. Concentration levels of acrylamide ( $\mu \mathrm{g} / \mathrm{L})$ in the influents of 6 STPS.

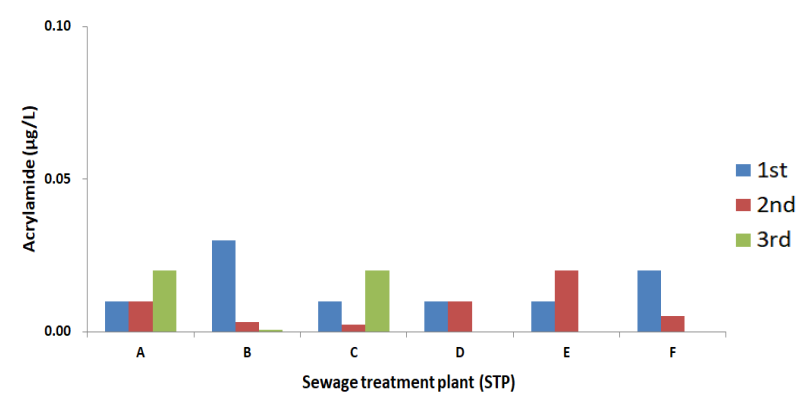

Fig. 8. Concentration levels of acrylamide ( $\mu \mathrm{g} / \mathrm{L})$ in the final effluents of 6 STPs.

데이터베이스 구축 연구에서 한강 수계 중 중량천 시료에 서 아크릴아마이드 함량이 $0.0025 \mu \mathrm{g} / \mathrm{L}$ 검출되었다는 보고 ${ }^{11)}$ 는 본 연구의 하수종말처리장의 방류수 수준과 비슷한 결과였다. 또한 외국 사례의 경우 미국 네바다주의 하수종 말처리장에서는 검출되지 않았으나 생수 등 가공된 물에서 는 $0.008 \sim 1.0 \mu \mathrm{g} / \mathrm{L}$ 검출되었다는 보고가 있다. ${ }^{32)}$

아크릴아마이드는 수중에서 약 8 12일 동안 74 94\% 생 분해된다고 알려져 있으며 ${ }^{33,34)}$ 아크릴아마이드의 분해는 nitrile hydratase (EC 4.2.1.84)와 amidase (EC 3.5.1.4) 같은 효소작용에 의하여 아크릴아마이드는 acrylic acid와 암모 니아로 분해된다고 보고한 바 있다. ${ }^{35,36)}$
본 연구에서도 아크릴아마이드의 제거율이 75.6 100\% 되었으나, 이와 같은 제거율은 미생물 작용에 의한 것인지 살균처리 시설 ${ }^{37)}$ 의 $\mathrm{UV}$ 에 의한 것인지는 좀 더 연구가 필 요할 것으로 생각된다. 또한, 유입수 내에 존재하는 아크릴 아마이드도 산업 활동에 의한 것인지 음식물 쓰레기에서 기인된 것인지도 향후 연구대상이 될 것으로 생각된다.

\section{4. 결 론}

본 연구는 수질 측정용 시료에서 아크릴아마이드에 관한 분석방법이다. 추출과 정제를 동시에 할 수 있는 SPE법을 적용하고 가스크로마그래피/질량분석법을 이용하였다. 시판 되고 있는 4 가지 SPE 상품(Supelclean ${ }^{\mathrm{TM}}$ Coconut Charcoal, $\mathrm{ENVI}^{\mathrm{TM}}$-Carb, ODS C18, Oasis HLB)을 비교하였다.

또한 유도체화 반응의 최적화를 통하여 특정수질유해물 질로 알려진 아크릴아마이드 분석의 최적조건을 확립하기 위하여 수행되었다. 정립된 방법에 따라 대전, 충남·북 지 역의 하수 종말처리장 6곳의 유입수와 방류수의 아크릴아 마이드의 함량을 분석하고, 분석방법에 대한 유효성 검증 을 실시한 결과는 다음과 같다.

1) 고체상추출법의 지지체는 Supelclean ${ }^{\mathrm{TM}}$ Coconut Charcoal 카트리지가 $98.8 \%$ 회수율과 방해물질을 효과적으로 제 거할 수 있었고, 흡착된 아크릴아마이드 탈착용매의 최 적 부피는 $12 \mathrm{~mL}$ 로 나타났다.

2) 브롬 유도체화 반응의 최적 반응시간은 $4^{\circ} \mathrm{C}$ 에서 3 시간이 었으며, 브롬 치환반응 생성물 2,3-DBPA와 $\mathrm{d}_{3}-2,3-\mathrm{DBPA}$ 의 추출용매는 에틸아세테이트가 가장 양호하였다.

3) 아크릴아마이드 표준용액의 농도 $2.5 \sim 100 \mu \mathrm{g} / \mathrm{L}$ 범위에 서 상관계수 값이 0.9981 로 고도의 상관성을 갖는 직 선성을 나타내었으며, 방법검출한계 및 정량한계 각각 $1.19 \mu \mathrm{g} / \mathrm{L}$ 및 $3.79 \mu \mathrm{g} / \mathrm{L}$ 이었다.

4) 확립된 시험방법에 따라서 분석한 결과 6 개의 하수종 
말처리장 방류수의 아크릴아마이드 함량은 5월 $0.008 \sim 0.017 \mu \mathrm{g} / \mathrm{L}, 6$ 월 0.009 0.14 $\mu \mathrm{g} / \mathrm{L}, 7$ 월 N.D. 0.02 $\mu \mathrm{g} / \mathrm{L}$ 의 분포를 보였다.

\section{References}

1. D. S. Mottram, B. L. Wedzicha, A. T. Dodson, Food chemistry: Acrylamide is formed in the Maillard reaction, Nature, 419(6906), 448-448(2002).

2. R. H. Stadler, I. Blank, N. Varga, F. Robert, J. Hau, P. A. Guy, M. C. Robert, Food chemistry: Acrylamide from Maillard reaction products, Nature, 419(6906), 449-449(2002).

3. J. M. Kim, J. H. Choi, Y. S. Choi, D. J. Han, H. Y. Kim, M. A. Lee, H. K. Chung, C. J. Kim, Effects of frying time and temperature on formation of acrylamide and sensory evaluation in French fries, Korean J. Food Sci. Technol., 41, 471-475(2009).

4. R. Zamora, F. J. Hidalgo, Contribution of lipid oxidation products to acrylamide formation in model systems, J. Agr. Food Chem., 56, 6075-6080(2008).

5. P. S. Spencer, H. H. Schaumberg, A review of acrylamide neurotoxicity, Canad. J. Neurol. Sci., 1, 152-169(1974).

6. J. W. Donovan, T. O. Pearson. Ingestion of acrylamide with severe encephalopathy, neurotoxicity and hepatotoxicity (Abstract), Vet Human Toxico., 29, 462 471(1987).

7. International Agency for Research on Cancer (IARC), Some industrial chemicals, Lyon: IARC, IARC Monographs on the evaluation for carcinogenic risk of chemicals to humans, 60 , 435-453(1994).

8. FAO/WHO, FAO/WHO consultation on the health implications of acrylamide in food, 25-27(2002).

9. Korea Ministry of Environment, Study on extended authorization of specific toxic substance and establishment of the effluent standard(II)(2013).

10. National institute of environmental research republic of Korea, Study on extended authorization of specific toxic substance and establishment of the effluent standard, 8th Year Report(2009).

11. National institute of environmental research republic of Korea, Monitoring and prediction system development of potentially hazardous materials in the Han River Basin, 5th Year Report(2011).

12. S. H. Kim, J. H. Hwang, K. G. Lee, Analysis of Acrylamide Using Gas Chromatography-Nitrogen Phosphorus Detector (GC-NPD), Food Sci. Biotechnol., 20, 835-839(2011).

13. Y. Zhu, G. Li, Y. Duan, S. Chen, C. Zhang, Y. Li, Application of the standard addition method for the determination of acrylamide in heat-processed starchy foods by Gas Chromatography with Electron Capture Detector, Food Chem., 109, 899-908(2008).

14. Z. Geng, P. Wang, A. Liu, Determination of acrylamide in starch-based foods by HPLC with precolumn Ultraviolet Derivatization, J. Chromatogr. Sci., 49, 818-824(2011).

15. L. Castle, Determination of acrylamide monomer in mushrooms grown on polyacrylamide gel, J. Agric. Food Chem., 41, 1261-1263(1993).

16. A. Yasuhara, Y. Tanaka, Hengel, M. T. Shibamoto, Gas chromatographic investigation of acrylamide formation in browning model system, J. Agric. Food Chem., 51, 3999-4003(2003).

17. M. Biedermann, S. Brem, V. Mozzetti, K. Grob, Experiments on acrylamide formation and possibilities to decrease the potential of acrylamide formation on potatoes, Mitt. Lenbensm. Hyg., 93, 668-687(2002).

18. M. Negoita, A. Culetu, Application of an accurate and validated method for identification and quantification of acrylamide in bread, biscuit and other bakery product using GC-MS/MS system, J. Braz. Chem. Soc., 27(10), 1782-1791 (2016).

19. H. W. Chung, S. K. Park, D. M. Choi, Determination of acrylamide in food products, Anal. Sci. Technol., 20(2), 164-169(2007).

20. M. Negoita, M. Catana, E. Iorga, L. Catana, N. Belc, Determination of acrylamide in bread by gas chromatography-tandem mass spectrometry, Rom. Biotechnol. Lett., 19(4), 9561-9567(2014).

21. C. T. Kim, E. S. Hwang, H. J. Lee, An improved LC-MS/MS method for the quantitation of acrylamide in processed foods, Food Chem., 101, 401-409(2007).

22. Korea Ministry of Environment, Korea Standard Methods for the Examination of Water and Wastewater(2011).

23. H. W. Chung, S. K. Park, D. M. Choi, Determination of acrylamide in food products, Anal. Sci. Technol., 20(2), 164-169(2007).

24. U. S. Environmental Protection Agency, Acrylamide by gas chromatography, SW 846 Method 8032A, EPA, Washington, DC(1996).

25. M. J. Garcia-Galan, M. S. Diaz-Cruz, D. Barcelo, Analysis, behavior and ecotoxicity of carbon-based nanomaterials in the aquatic environment, 28(6), 804-819(2009).

26. J. L. Feng, D. Y. Chen, D. Zeng, H. Zhang, L. Ding, Y. H. Wang, B. R. Li, Determination of Acrylamide in Water by Liquid Chromatography Coupled to Tandem Mass Spectrometry, LC-GC Asia Pacific, 17(2), 6-11(2014).

27. W. C. Cheng, S. W. Hsiao, S. S. Chou L. S. Hwang, Determination of acrylamide in Chinese foods by GC-Ion Trap MS using 2-bromopropenamide and 2-bromopropenamide- ${ }^{13} \mathrm{C}_{3}$, J. Food Drug Anal., 14(2), 207-214(2006).

28. B. Dorin, A. Simin, A. Seyed, A. Yasini, Determination of the amount of acrylamide formation during frying of potato in sesame oil, palm olein and the blend of them, Int. J. Eng. Res. Appl., 3(6), 2248-2253(2013).

29. J. Y. Eom, Analysis of acrylamide in processed food by GC/MS \& effect of organic acid on the formation of acrylamide, MS Dissertation, Seoul National University, Seoul, KOR(2004).

30. M. Katerina J. L. Steven, A. Michelangelo, Combination of analyte protectants to overcome matrix effects in routine GC analysis of pesticide residues in food matrixes, Anal. Chem 77, 8129-8137(2005). 
31. C. Magda, M. Natalia, S. Piotr, K. Marek, K. Jolanta, Matrix effects and recovery calculations in analyses of pharmaceuticals based on the determination of $\beta$-blockers and $\beta$-agonists in environmental samples, J. Chromatogr. A, 1258, 117-127(2012).

32. P. D. DeArmond, A. L. DiGoregorio, Characterization of liquid chromatography tandem mass spectrometry method for the determination of acrylamide in complex environmental samples, Analytical and Bioanalytical Chemistry, 405(12), 4159-4166(2013).

33. S. S. Lande, S. J. Bosch, P. H. Howard, Degradation and leaching of acrylamide in soil, Journal of Environmental Quality, 8, 133-138(1979).

34. Y. Asano, M. Tachibana, Y. Tani, H. Yamada, Purification and characterization of amidase which participates in nitrile degradation. Agricultural and Biological Chemistry, 46(5), 1175-1181(1982).

35. C. C. Wang, C. M. Lee, Denitrification with acrylamide by pure culture of bacteria isolated from acrylonitrile-butadiene- styrene resin manufactured wastewater treatment system, Chemosphere, 44, 1047-1053(2001).

36. M. Cha, G. H. Chambliss, Characterization of acrylamidase isolated from a newly isolated acrylamide-utilizing bacterium, Rastonia eutropha AUM-01, Current Microbiology, 62(2), 671-678(2011).

37. J. Rosen, K. E. Hellenas, Analysis of acrylamide in cooked foods by liquid chromatography tandem mass spectrometry, Analyst, 127, 880-882(2002).

38. L. Lucentini, E. Ferretti, E. Veschetti, L. Achene, M. Ottaviani, Determination of low-level acrylamide in drinking water by liquid chromatography/tandem mass spectrometry, J. of AOAC international, 92(1), 263-270(2009).

39. H. H. Lim, H. S. Shin, Ultra trace level determinations of acrylamide in surface and drinking water by GC-MS after derivatization with xanthydrol, J. Sep. Sci., 36, 3059-3066(2013).

40. H. S. Canbay, M. Doganturk, Analysis of acrylamide in drinking water by SPE and GC-MS, Applied Water Science, 9(42), 1-4(2019). 